\title{
Meteorological, soil moisture, surface water, and groundwater data from the St. Denis National Wildlife Area, Saskatchewan, Canada
}

\author{
Edward K. P. Bam ${ }^{1}$, Rosa Brannen ${ }^{1}$, Sujata Budhathoki ${ }^{1}$, Andrew M. Ireson ${ }^{1}$, Chris Spence ${ }^{2}$, and \\ Garth van der Kamp ${ }^{1,2}$ \\ ${ }^{1}$ Global Institute for Water Security, University of Saskatchewan, Saskatoon, S7N3H5, Canada \\ ${ }^{2}$ National Hydrology Research Centre, Environment and Climate Change Canada, Saskatoon, S7N3H5, Canada
}

Correspondence: Edward K. P. Bam (edward.bam@usask.ca) and Andrew Ireson (andrew.ireson@usask.ca)

Received: 1 October 2018 - Discussion started: 24 October 2018

Revised: 7 March 2019 - Accepted: 19 March 2019 - Published: 26 April 2019

\begin{abstract}
The St. Denis National Wildlife Area is located in the seasonally frozen and semi-arid Canadian Prairies, close to Saskatoon, Saskatchewan. The site has a hummocky terrain and is underlain by clay-rich glacial tills. Though the site is only $4 \mathrm{~km}^{2}$ it contains hundreds of wetlands containing ponds which range in size, in permanence (from ephemeral to permanent), and in their interactions with groundwater (recharge and discharge ponds are present). The site was established as a research area in 1968 and has long-term records of hydrological observations, including meteorological, snow, soil moisture, surface water (ponds) and groundwater data. Some records, notably the pond level and chemistry data, span the period 1968 to present. Other datasets, notably water level observations from networks of piezometers, have been collected sporadically at different locations and times. Some datasets are collected manually on an annual basis, including pond surveys and snow surveys. Meteorological data have been collected by automatic weather stations since 1989 and have been maintained and upgraded over time, with a flux tower added to the site in 2011. Automatically logged soil moisture profiles and collocated piezometers have been running since 2013. A lidar survey from 2005 provides a $1 \mathrm{~m}$ resolution digital elevation map (DEM) of the site and surrounding landscape. The compiled data are available at https://doi.org/10.20383/101.0115 (Bam et al., 2018).
\end{abstract}

\section{Introduction}

The Canadian portion of the North American Prairies is bounded to the west by the Rocky Mountains and the north and east by the boreal forest. It contains around $80 \%$ of Canada's agricultural area, with an annual crop market value in 2016 of USD 41 billion (Statistics Canada, 2017). The region is characterized by a semi-arid, seasonally frozen climate, with colder and wetter conditions moving from southwest to northeast. The surficial geology is dominated by glacial till, interspersed with glacio-lacustrine sand and gravel deposits, and the glaciated landscape is generally flat or gently rolling, with thousands of depressions. Due to the low amounts of precipitation, drainage networks are poorly developed, and precipitation excess tends to form lakes and wetlands in surface depressions (Hayashi et al., 2016). Surface water bodies in the depressions have widely varying sizes, from large permanent lakes, such as Redberry Lake, Saskatchewan (van der Kamp et al., 2008), to ponds that rarely dry out, to ephemeral ponds that dry out annually. Farming practices over the past century include widespread artificial wetland drainage in some portions of the region (Rashford et al., 2011).

Within this prairie landscape, the St. Denis National Research Area (Fig. 1) was established in 1968 by the Canadian Wildlife Service for research on how agricultural practices affect waterfowl production. The site was primarily selected because it was a cultivated land parcel with an abundance of wetlands close to the City of Saskatoon. The St. Denis National Research Area was officially listed in the Canada 
Gazette with an amendment to the Wildlife Area Regulations in 1978 (SOR/78-466). The St. Denis National Research Area is the only site in the Environment and Climate Change Canada protected areas' network to bear the title of "National Research Area"; however, the colloquial name of the reserve is St. Denis National Wildlife Area (SDNWA).

At the time of establishment, nearly $60 \%$ of the 361.5 ha in the SDNWA was under cultivation, with the remainder a mix of native grasslands, shrublands, and wetlands. As far as we are aware, no wetland drainage has occurred on the site, though we cannot be certain about what happened prior to 1968 when the site was established as a National Research Area. Lease agreements with local farmers are used to keep the annual cropland in production with wheat, barley, and canola, while the remainder of the vegetation remains undisturbed. In 1977, a program was initiated to convert 97 ha of cultivated land to a perennial forage mix of smooth brome (Bromus inermis) and alfalfa (Medicago sativa) (van der Kamp et al.,1999). The program was to minimize erosion on sloping and light textured soils from tillage activities, to provide nesting cover and food for wildlife, and was consistent with land use changes in the surrounding region. There were minor changes in land cover until 2015 when a seeding program began to convert the remaining cropland back to permanent grassland cover.

The SDNWA and surrounding landscape area is hummocky, with local relief of the order of $15 \mathrm{~m}$. The area lies within and near the lower end of a 2400 ha closed watershed for which detailed lidar elevation data are available. Aspen bluffs occupy some of the larger depressions in the drainage basin. Soils are predominantly Dark Brown Chernozems and Orthic Regosols; both are developed from glacial till (Miller et al., 1985). The glacial stratigraphy of the site is welldocumented: roughly $100 \mathrm{~m}$ of clay-rich glacial till of low permeability lies under the soils, interspersed with isolated sand lenses and a continuous thin layer of sand at about 25 to $30 \mathrm{~m}$ depth (Hayashi et al., 1998).

The SDNWA is a site that is unrivaled in the Canadian Prairies for the length and breadth of hydrological observations (Pennock et al., 2013, provide a good summary of the site and the research history). Over the past 50 years, field research has been undertaken at SDNWA by hydrologists, hydrogeologists, biologists, ecologists, soil scientists, and others, and there have been more than 100 papers published on this site. Many of these studies were based on short-term field experiments, which have produced snapshots of data in time. Here, we focus on the continuous monitored program, which is ongoing and is the foundation of much of the short-term research. The longest records are of pond levels and chemistry, dating back to 1968. Soil and groundwater observations have been recorded continuously since 2013 (before this there are large amounts of groundwater data, but those observations are not continuous to present).

\section{Meteorological data}

There are two climate stations at the St. Denis National Wildlife Area. The older, a $10 \mathrm{~m}$ mast tower, is at an elevation of $554 \mathrm{~m}$ a.s.l. at $52.2037^{\circ} \mathrm{N}, 106.1067^{\circ} \mathrm{W}$ located on the upland south of Wetland 50 surrounded by brome-alfalfa grassland (Fig. 1). This station was initially deployed in the spring of 1989 as part of the Wetlands Ecosystem Vulnerability Study (WEVS). It was initially used to evaluate the water budgets of prairie wetlands, particularly Wetland 50 (Woo and Rowsell, 1993). From 1991 to 1998 operation of the station was transferred to the Meteorological Service of Canada. In 1998, the equipment was transferred to the Canadian Wildlife Service (CWS), for continuing use as a WEVS facility. Reorganization of the CWS in 2006 prompted responsibility of the tower to be transferred to the Water Directorate of the Science and Technology Branch of Environment and Climate Change Canada. These transfers sometimes resulted in substantial breaks in the period of record. In 2011, a second climate tower was constructed that was capable of supporting eddy covariance equipment for measuring turbulent energy and carbon fluxes and all component net radiation. This is a $10 \mathrm{~m}$ scaffolding tower located at $52.2089^{\circ} \mathrm{N}$, $106.0889^{\circ} \mathrm{W}$ at a local high point in a field currently supporting dense nesting cover (Fig. 1). The specifics of each tower, including variables and units and sensor types and heights, are summarized in Table 1. Three-dimensional wind speeds, air temperature, water vapor content, and carbon dioxide density are measured at $10 \mathrm{~Hz}$ with turbulent fluxes calculated over a half-hour period on the Campbell Scientific CR3000 logger. The turbulent flux data within these records are uncorrected and should be treated with caution. All meteorological data are observed every $5 \mathrm{~s}$, and half-hourly averages (or totals) are currently logged on Campbell Scientific CR1000 (mast tower) and CR3000 (scaffolding tower) data loggers. Rainfall data, measured with Texas Electronics TE525M tipping bucket rain gauges, are reported as the hourly or half-hourly totals. It is important to note that while the tipping bucket rain gauges are in operation all year and may record precipitation during the winter months, they only supply reliable measurements of liquid precipitation when not accompanied by freezing or frozen precipitation. Figure 2 shows the record of yearly rainfall (which may be significantly less than total precipitation) and air temperature at the site.

\section{Snow surveys}

Snow surveys have been conducted at SDNWA by Environment and Climate Change Canada (ECCC) since 1994. Snow depths and densities are measured along three transects (Fig. 1) and converted to snow water equivalent (SWE) and then generalized over the whole site (Fig. 3). The snow surveys are performed once each year in March to estimate the SWE on the ground before snowmelt begins. One of the snow 


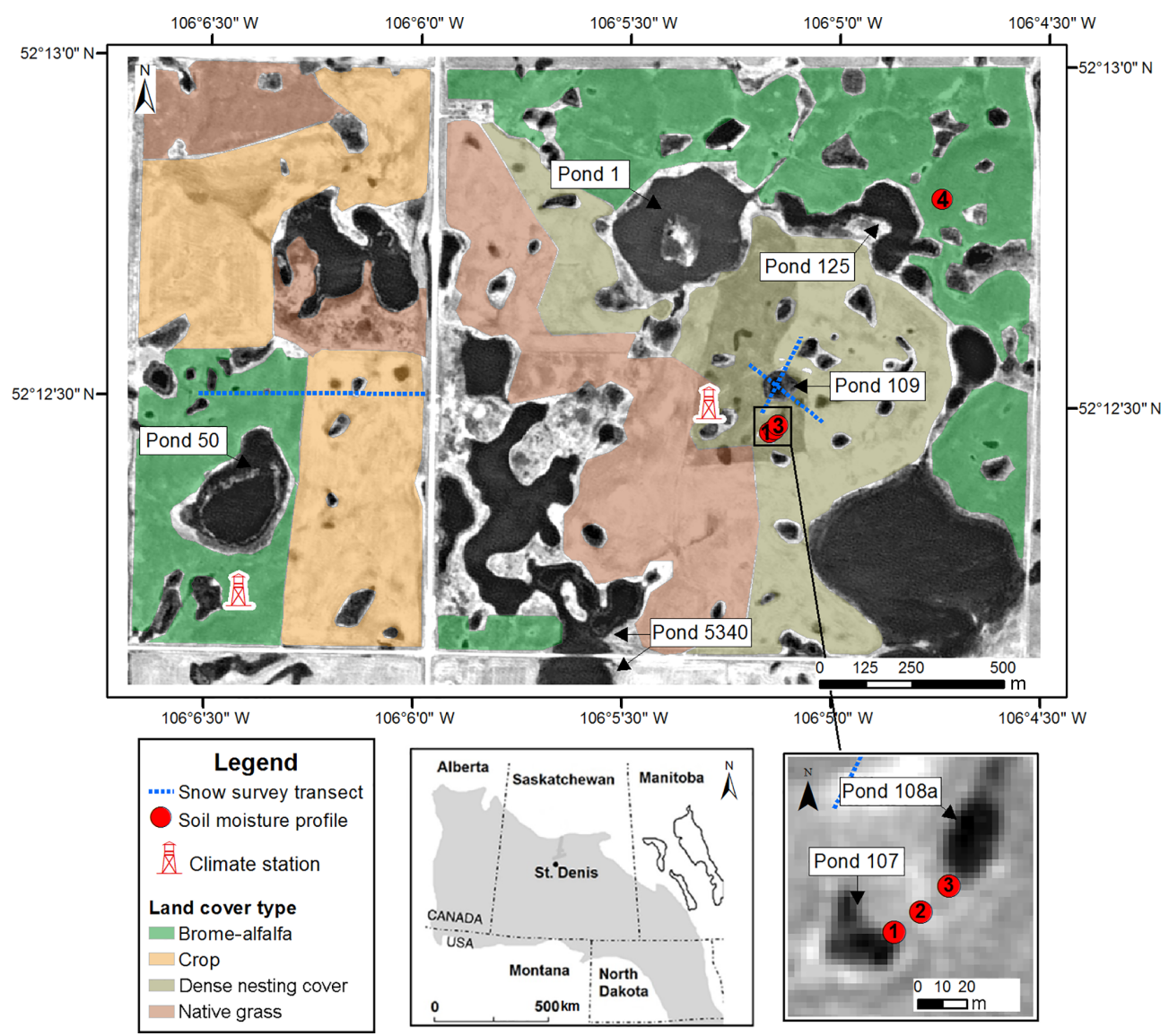

Figure 1. Map and location of St. Denis National Wildlife Area. The grey area on the inset map represents the extent of Prairie Pothole Region in North America.

Table 1. Long-term meteorological instrumentation at St. Denis National Wildlife Area.

\begin{tabular}{lrl}
\hline Variable & Height $(\mathrm{m})$ & Sensor \\
\hline $10 \mathrm{~m}$ mast & & \\
\hline Wind speed $\left(\mathrm{m} \mathrm{s}^{-1}\right)$ & 10 & RM Young 5103 \\
Wind direction $\left({ }^{\circ}\right)$ & 10 & RM Young 5103 \\
Air temperature $\left({ }^{\circ} \mathrm{C}\right)$ and relative humidity $(\%)$ & 2 & Vaisala HMP series \\
Photosynthetically active radiation $\left(\mathrm{W} \mathrm{m}^{-2}\right)$ & 1 & LiCor Li190SB \\
Incoming solar radiation $\left(\mathrm{W} \mathrm{m}^{-2}\right)$ & 1 & LiCor Li200X \\
Rainfall (mm) & 0.5 & Texas Electronics TE525M \\
\hline 10 m scaffolding tower & & \\
\hline Wind speed (m s $\left.{ }^{-1}\right)$ & 2 & Met One 14A \\
Wind direction $\left({ }^{\circ}\right)$ & 10 & NRG \\
Air temperature $\left({ }^{\circ} \mathrm{C}\right)$ and relative humidity $(\%)$ & 10 & Vaisala HMP series \\
Air temperature $\left({ }^{\circ} \mathrm{C}\right)$ and relative humidity $(\%)$ & 1.5 & Vaisala HMP series \\
All component radiation $\left(\mathrm{W} \mathrm{m}{ }^{-2}\right)$ & 10 & Kipp and Zonen CNR4 \\
Turbulent fluxes $\left(\mathrm{C}\right.$, Qe, Qh) $\left(\mathrm{W} \mathrm{m}^{-2}\right)$ & 10 & Campbell Scientific CSAT3; EC150 \\
Rainfall (mm) & 10 & Texas Electronics TE525M \\
\hline
\end{tabular}



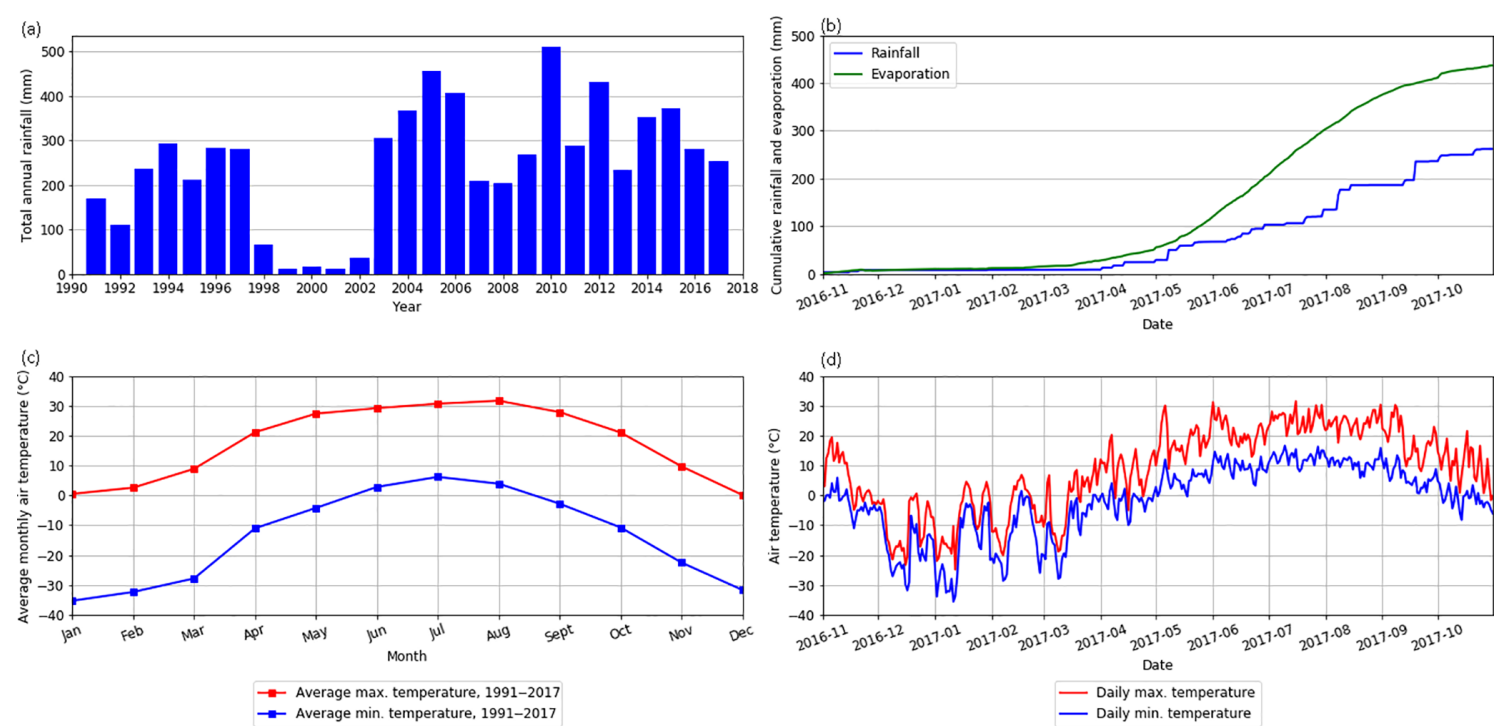

Figure 2. Meteorological data from SDNWA: (a) the total annual rainfall for the period of record (1991-2017) measured at the mast tower; (b) cumulative total rainfall (mast tower) and evaporation (scaffold tower) for the 2016-2017 hydrologic year; (c) mean monthly air temperature at $2 \mathrm{~m}$ (mast tower) for the period of record (1991-2017); and (d) daily air temperature at $2 \mathrm{~m}$ (mast tower) for the 2016-2017 hydrologic year.

surveys consists of two perpendicular transects that cross in the center of Wetland 109. Each transect is approximately $250 \mathrm{~m}$. Snow depth is measured at every 5 to $10 \mathrm{~m}$. At every fifth depth measurement, a density sample is collected using an Eastern Snow Conference snow tube (ESC-30, Goodison et al., 1987). This survey measures snow accumulation in the grass, wetland vegetation, trees, and an ice-covered pond. The other snow survey is a $700 \mathrm{~m}$ transect that runs east to west through cropped and grass fields across the western portion of the SDNWA. Snow depths are measured every $15-20 \mathrm{~m}$, and density samples are taken every fifth depth measurement. SWE values are calculated for each point and then averaged to calculate mean SWE for each land cover. The average SWE over the entire SDNWA is estimated by calculating a weighted mean by a land cover fraction of the total area.

\section{Pond water level, chemistry, and bathymetry data}

At the St. Denis National Wildlife Area pond water depths in wetlands have been monitored since 1968. These wetlands generally have areas between 0.1 and 10 ha and contain ponds that range in class from vernal to ephemeral to permanent. SDNWA wetlands were initially mapped based on aerial photography (Hogan and Conly, 2002) and numbered. The major wetlands were numbered 1 to 147 , and smaller wetlands adjacent or adjoined to the larger depressions were sub-labeled with letters a, b, c, and d.

The record of pond depth measurements dates from 1968 to 2017 and includes measurements from 135 ponds. Canadian Wildlife Service staff began monitoring 76 of the SD-

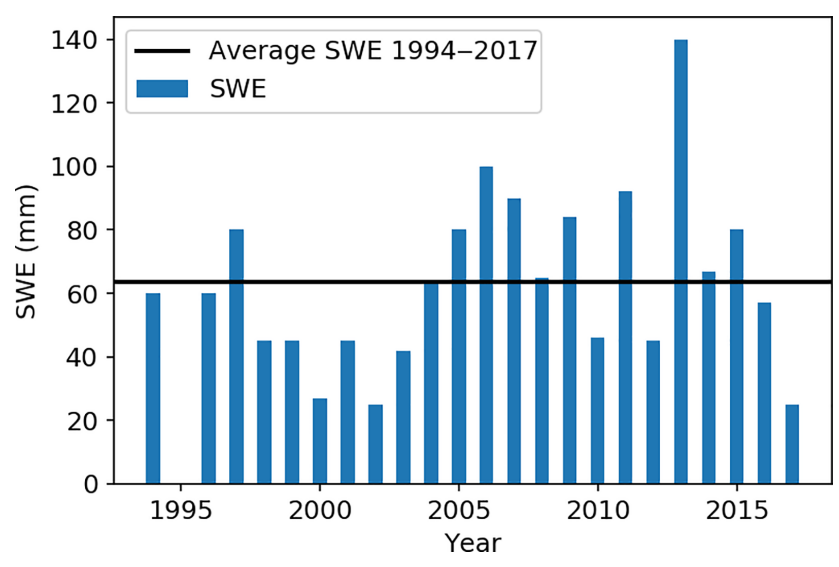

Figure 3. Weighted mean snow water equivalent (SWE; blue bars) of snowpack before melt over SDNWA. The black line represents the 24-year average of snow accumulation.

NWA wetlands in 1968; an additional 57 started being monitored after 2011. The frequency of measurement varies annually and among wetlands. Monitoring typically begins in spring and extends through to the fall. Measurements are not conducted during the winter because many ponds will freeze to the sediment and because snow and ice accumulation on ponds influence water depth under ice. There are some wetlands with data available for every year from 1968 to the present (Wetland 25, Wetland 50, Wetland 65, Wetland 90, Wetland 109, and Wetland 120). Many were dry during the drought of 1999-2002. In 2015, a long-term monitoring plan was developed jointly with researchers from the University 
of Saskatchewan and ECCC to monitor pond depths, stable isotopes, and water quality of 25 wetlands once each in May, July, and October.

The methodology for collecting pond depth data is described in Conly et al. (2004). The lowest bottom elevation in the wetland depression is used as the relative datum, and the geodetic elevations of these points have been determined for many of the wetlands. Measurements are made by wading into the pond and using a measuring rod to measure water depth at monitoring markers (usually a metal T-bar installed deep into pond sediments to prevent heaving or movement). The measuring rod is attached to a $6 \mathrm{~cm}$ diameter circular base to prevent the rod from being pushed into the sediment. Shallow seasonal and ephemeral ponds require only a single marker. Deeper ponds that vary considerably in flooded area and depth have multiple markers installed at various elevations to ensure a measurement can be made when markers installed at lower elevations are flooded. Depth measurements are taken at the same time at multiple markers to ensure markers are tied to the local datum. Point measurements at single markers (in smaller wetlands) are generally within $25 \mathrm{~mm}$ of those measured with conventional survey equipment and benchmarks. The accuracy in larger wetlands is considered to be within $50 \mathrm{~mm}$ (Conly et al., 2004). The yearto-year and seasonal variations in pond water levels are apparent from the long-term record (Fig. 4).

Water chemistry of ponds and groundwater has been measured in a number of studies at St Denis National Wildlife Area (e.g., Hayashi et al., 1998; Berthold et al., 2004; Waiser 2006; Heagle et al., 2007, 2013; Pennock et al., 2010, 2013). The record consists of measurements of individual ions and overall solute load measures, i.e., electrical conductivity (EC; Fig. 5) and total dissolved solids (TDS). The details of the equipment and methods are described in Hayashi et al. (1998), Berthold et al. (2004), Waiser (2006), Heagle et al. (2007, 2013), and Pennock et al. (2010).

Detailed elevation surveys were carried out in 1994, 1998, 1999, 2008, and 2009 on 26 wetland depressions using electronic total stations within the SDNWA. The catchment extent of the wetlands and depressions, vegetation, soil, and the hydroperiods of ponds in the respective wetlands are published in Hayashi and van der Kamp (2000) and Minke et al. (2010). Survey points were spaced horizontally at 10$15 \mathrm{~m}$ intervals in the uplands, 5-10 $\mathrm{m}$ intervals in the wetlands, and 2-5 m intervals in small depressions. The estimated measurement error is within a few centimeters for elevation and within a few tens of centimeters for horizontal location (Hayashi and van der Kamp, 2000; Minke et al., 2010). The water depth data for these wetlands (Fig. 4) can be presented as water surface elevation for comparison with groundwater levels.

\section{Soil moisture data}

There are four soil moisture profiles at SDNWA, where continuous observations of water content, matric potential, temperature, and electrical conductivity have been made since July 2013. Three of these profiles are located along a lowland transect between ephemeral ponds (107 and 108a) adjacent to Wetland 109, and one profile is located towards the top of a hillslope east of Wetland 1 (Fig. 1). In each case, piezometers are collocated with the soil moisture profiles, as described below.

HydraProbe sensors (Hydra II, Stevens Water Monitoring Systems Inc., 2007) are impedance sensors that simultaneously measure soil volumetric water content, soil temperature, and electrical conductivity. The probes were installed at depths of 5, 20, 50, 100, 200, and $300 \mathrm{~cm}$ in all soil profiles. During soil freezing the dielectric constant of ice is much lower than that of liquid water, so the instrument is likely to give a reasonable measure of the liquid water content (Spaans and Baker, 1995). The soil matric potential is measured using the heat dissipation sensors (229 probes, Campbell Scientific Inc. 2009) at depths of 5, 20,50, and $100 \mathrm{~cm}$. The heat dissipation sensor is a porous block sensor which measures the pressure of dry soil and has a working range of -10 to $-2500 \mathrm{kPa}$. Tensiometers (T4e, Decagon Devices) are used to measure the pressure of wet soil at depths of 100, 200, and $300 \mathrm{~cm}$. The working range of the tensiometer is +100 to $-85 \mathrm{kPa}$. The soil freezing temperature and moisture content for three profiles at $20 \mathrm{~cm}$ near Wetland 109 are shown in Fig. 6a and b. Figure 7 shows the observed soil water content and soil freezing characteristic of profile 1 (Fig. 1) at depths of 5 and $20 \mathrm{~cm}$ at St. Denis.

\section{Groundwater level data}

The hydrogeology of St. Denis is reasonably complex, comprising shallow and relatively high permeability weathered till layers overlying unweathered till aquitards and coarse-grained intertill confined aquifers. A large number of piezometers were installed in all three of these units, mostly for individual short-term projects, and as a result most of the data are discontinuous. These data are nonetheless available and provide useful insights into the spatially and temporally variable interactions between groundwater and surface water bodies. Continuous monitoring of the water table started in 2013 at a piezometer near Wetland 109 collocated with the soil moisture transects. Two piezometers were installed in a confined aquifer and instrumented in November 2013. These are the deepest piezometers on the site (39 and $41 \mathrm{~m}$ below ground level). Unvented Solinst Leveloggers are used to monitor water levels, corrected for changes in barometric pressure with a Solinst BaroLogger placed at the scaffolding climate tower. Figure 8 shows groundwater and surface water levels at SDNWA for 2014 to 2016. 


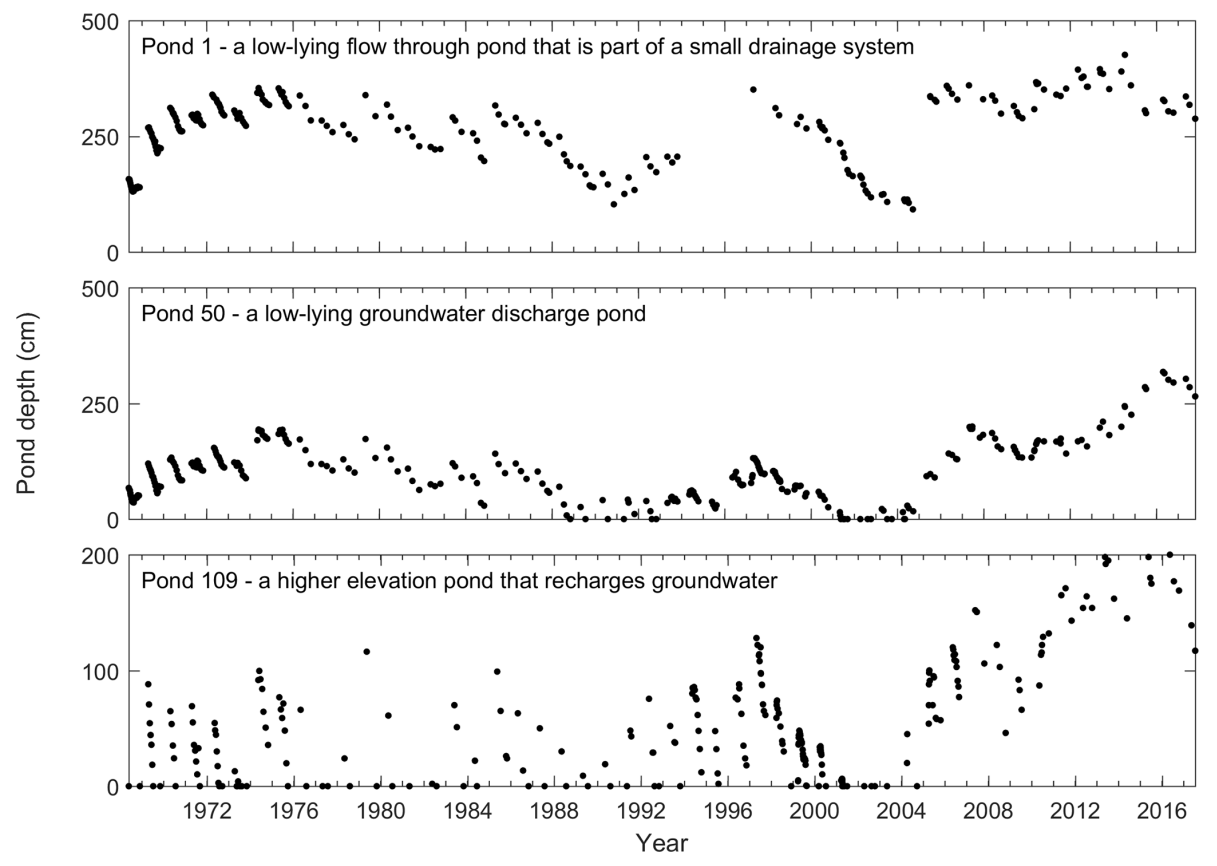

Figure 4. Pond level fluctuations with time in Wetland 1, 50, and 109.

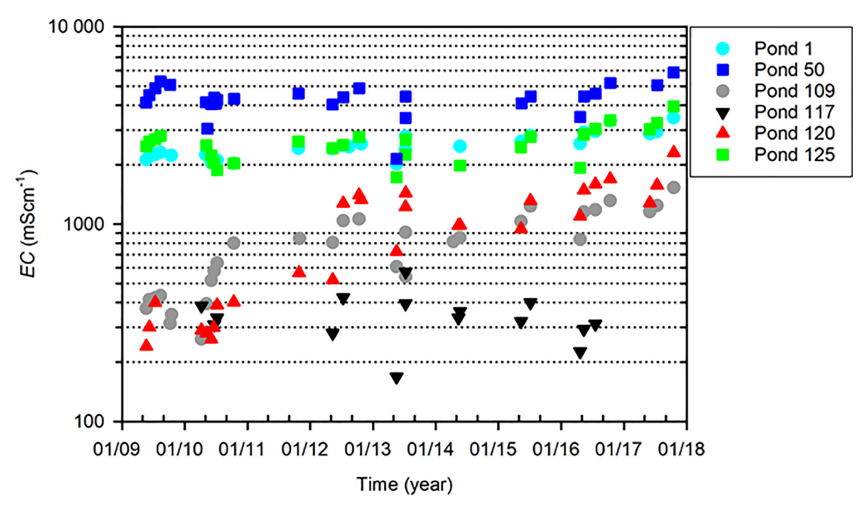

Figure 5. Time series of pond water electrical conductivity (log scale) at St. Denis showing the variations in pond salinity.

\section{Water isotope data}

Stable isotopes of water $\left(\delta^{18} \mathrm{O}\right.$ and $\left.\delta^{2} \mathrm{H}\right)$ have been measured sporadically for some of the ponds at St. Denis since 1993. These data are complemented by campaign-based samples of rainfall, snow (mainly in the period 2013-2014), and groundwater (sporadic measurements between 1993 and 2014 and covering depths between 1.2 and $41 \mathrm{~m}$ below ground level). Furthermore, continuous snow and rainfall samples from Saskatoon, $35 \mathrm{~km}$ away, are available for the period 1993 to 2014. Isotope ratios of $\delta^{2} \mathrm{H}$ and $\delta^{18} \mathrm{O}$ of all samples were measured at the National Hydrology Research Centre in Saskatoon, Canada. The sampling and analysis methodology is described in detail in Lis et al. (2008).
Isotope ratios of tritium were measured at the Rafter Radiocarbon Laboratory, National Isotope Centre, GNS Science in New Zealand. The stable isotope ratios of water were analyzed using three instruments: a Micromass Optima continuous-flow mass spectrometer, Micromass IsoPrime dual-inlet/continuous-flow mass spectrometers, and an off-axis integrated cavity output spectroscopy (OA-ICOS) laser.

Between 1993 and 2007, the precipitation, ponds, and groundwater samples were analyzed for $\delta^{2} \mathrm{H}$ and $\delta^{18} \mathrm{O}$ using isotope-ratio mass spectrometry (IRMS). The protocols for the isotope-ratio mass spectrometer analysis follow the standard methods (Begley and Scrimgeour, 1997; Coleman et al., 1982; Eiler and Kitchen, 2001; Epstein and Mayeda, 1953; Karhu, 1997; Kelly et al., 2001; Socki, 1999). The ${ }^{18} \mathrm{O} /{ }^{16} \mathrm{O}$ ratio in the water samples was analyzed by the equilibration of water samples with $\mathrm{CO}_{2}$ gas at $25 \pm 0.1{ }^{\circ} \mathrm{C}$ for $24 \mathrm{~h}$ to produce $\mathrm{CO}_{2}$ gas (Epstein and Mayeda, 1953). After the equilibration, the $\mathrm{CO}_{2}$ gas was extracted and purified through a vacuum cryogenic line. The ${ }^{2} \mathrm{H} /{ }^{1} \mathrm{H}$ ratio was analyzed by the production of hydrogen gas using $\mathrm{Cr}$ at $850^{\circ} \mathrm{C}$ (Coleman et al., 1982). The ${ }^{18} \mathrm{O} /{ }^{16} \mathrm{O}$ and ${ }^{2} \mathrm{H} /{ }^{1} \mathrm{H}$ ratios were measured against the internal standards which were calibrated using Vienna Standard Mean Ocean Water (V-SMOW: $\delta^{2} \mathrm{H}=0.0$ and $\delta^{18} \mathrm{O}=0.0$ ) and Standard Light Antarctic Precipitation (SLAP: $\delta^{2} \mathrm{H}=-428.0 \%$ 。 and $\delta^{18} \mathrm{O}=-55.5 \% \circ$ ). The results were normalized to the VSMOW-SLAP scale and reported in the delta notation as described in Coplen (1988). The analytical reproducibility is $\pm 0.1 \%$ and $\pm 1.0 \%$ of $\delta^{18} \mathrm{O}$ and $\delta^{2} \mathrm{H}$. Both offline dual-inlet (i.e., zinc reduction or uranium reduction) and 


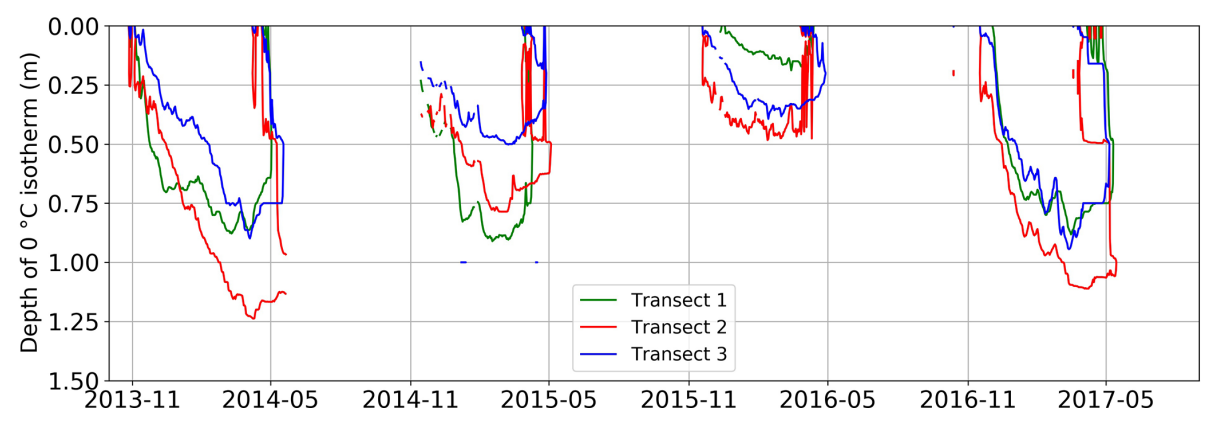

Figure 6. Soil freezing depths in three soil profiles near Wetland 109.
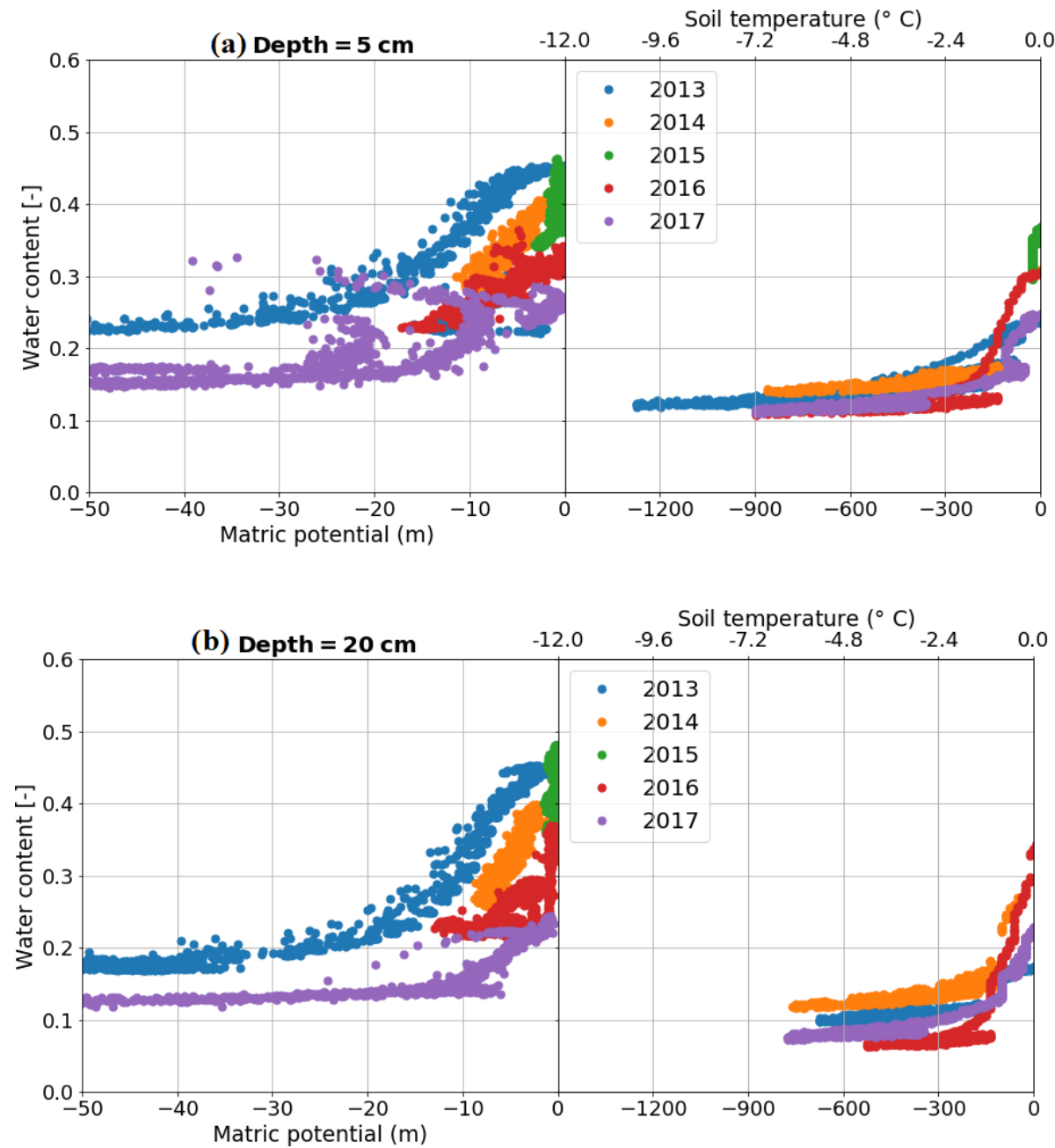

Figure 7. Observed soil water content and soil freezing characteristic of the upslope profile at depths of (a) 5 and (b) $20 \mathrm{~cm}$ at St. Denis. Note that the water content data for the freezing condition of 2015 are not recorded in (b) since soil temperature at a depth of $20 \mathrm{~cm}$ was always above $0{ }^{\circ} \mathrm{C}$.

continuous-flow (CF) IRMS methods (i.e., Cr reduction or C) have measurement accuracies of the order of $( \pm 0.5 \%$ o to $\pm 4 \%$ ) for $\delta^{2} \mathrm{H}$, and the automated CF-IRMS methods, such as $\mathrm{C}$ reduction to $\mathrm{CO}$ and $\mathrm{CO}_{2}-\mathrm{H}_{2} \mathrm{O}$ equilibration, are between $\pm 0.1 \%$ and $\pm 0.4 \%$ o for $\delta^{18} \mathrm{O}$ (Lis et al., 2008).
A Los Gatos Research DLT-100 liquid water isotope analyzer system coupled with a CTC LC-PAL liquid autosampler (Los Gatos Inc., California) was employed in stable isotope analyses done between 2008 and 2018 . The analysis follows the methods described in Lis et 


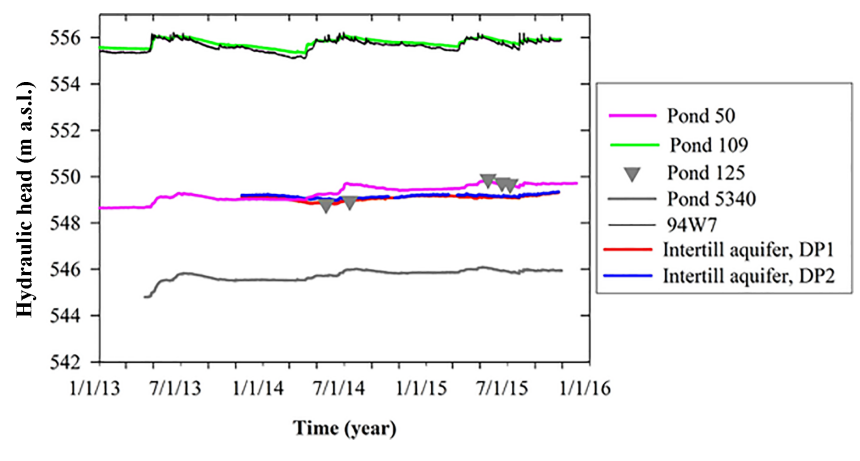

Figure 8. Groundwater and surface water levels at St. Denis.

al. (2008) and IAEA manual (2009). Laboratory standards (INV1: $\delta^{2} \mathrm{H}=-220.0 \% o, \delta^{18} \mathrm{O}=-28.5 \%$ and ROD3: $\delta^{2} \mathrm{H}$ $=-8.0 \%, \delta^{18} \mathrm{O}=-1.2 \%$ ) were calibrated with Vienna Standard Mean Ocean Water (V-SMOW2) and Standard Light Antarctic Precipitation (SLAP2) reference waters. INV1 and ROD3 were used to normalize the results to the VSMOW2-SLAP2 scale by assigning $\delta^{18} \mathrm{O}$ and $\delta^{2} \mathrm{H}$ values of $-55.5 \%$ and $-427.5 \%$, respectively, to the SLAP2 reference water. Consequently, all measured values reported are relative to the VSMOW-SLAP $\delta$ scale. Samples, standards, and control samples (river water) were analyzed six times. The laboratory precision was $\pm 1.0 \%$ for $\delta^{2} \mathrm{H}$ and $\pm 0.2 \%$ o for $\delta^{18} \mathrm{O}$.

Tritium $\left({ }^{3} \mathrm{H}\right)$ samples were shipped to Rafter Radiocarbon Laboratory, National Isotope Centre, GNS Science in New Zealand for ultra-low-level tritium counting using electrolytic enrichment and liquid scintillation counting (LSC). The ${ }^{3} \mathrm{H}$ concentrations are expressed in tritium units (TU); the precision at an average tritium concentration of New Zealand rain of $4 \mathrm{TU}$ is $\pm 0.06 \mathrm{TU}(98.5 \%)$, and the detection limit is \pm 0.025 TU (Morgenstern and Taylor, 2009). Details of the analytical procedure are provided in Morgenstern and Taylor (2009). A summary of the stable isotope data is shown in Fig. 9.

\section{Spatial data}

Elevation data of the SDNWA and surrounding area were collected during a light detection and ranging (lidar) survey conducted by the Canadian Consortium for Lidar Environmental Applications Research (C-CLEAR) on 9 August 2005. The exact methods of the lidar data survey and processing of the digital elevation model (DEM) are described in Töyrä et al. (2008). The generated DEM is provided in UTM Zone 13 NAD83, and the elevations are orthometric heights based on the CGG05 geoid model. The elevations are tied to a local benchmark near Wetland 1. The ground data points were interpolated into a $1 \mathrm{~m}$ DEM using the inverse distance weighted (IDW) algorithm. The lidar DEM was evaluated based on in situ survey data (GPS points and

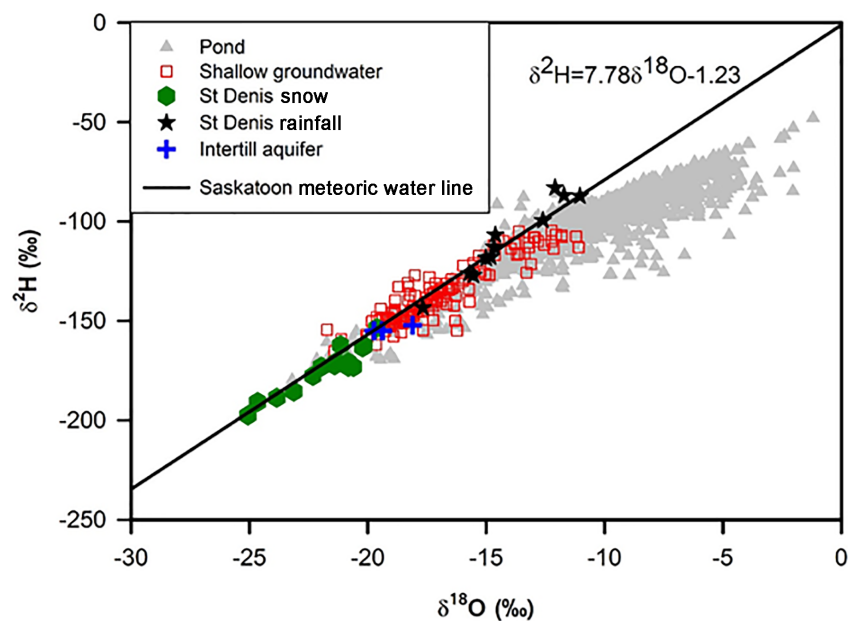

Figure 9. A scatter plot of $\delta^{2} \mathrm{H}$ versus $\delta^{18} \mathrm{O}$ at St. Denis, Saskatchewan.

total station surveys). The results indicate that the accuracy of lidar DEM in the agricultural fields or grasses is $0.13 \mathrm{~m}$, while the accuracy in the shrubs and trees surrounding the wetland ponds is $0.17 \mathrm{~m}$.

\section{Overview of content}

The record from both climate towers shows strong seasonality of incoming radiation and turbulent fluxes at the SDNWA. Maximum incoming solar radiation (typically $\sim 350 \mathrm{~W} \mathrm{~m}^{-2}$ ) occurs in June near the summer solstice. Conversely, minimum solar radiation of $10 \mathrm{~W} \mathrm{~m}^{-2}$ is in December. There is very little seasonal lag between incoming solar radiation and net radiation, which ranges from 200 to $-30 \mathrm{~W} \mathrm{~m}^{-2}$ between June and December. The record does include several spikes in the radiation and turbulent flux data that should be removed prior to any analysis. The mean of hourly wind speed over the period of record (1992-2018) is $3.8 \mathrm{~m} \mathrm{~s}^{-1}$. The period of record includes half-hourly mean wind speeds as high as $16.9 \mathrm{~m} \mathrm{~s}^{-1}$. Daily maximum air temperatures often reach $+27^{\circ} \mathrm{C}$ in July and can be well below $-30^{\circ} \mathrm{C}$ anytime between November and February (Fig. 2). These cold air temperatures are also associated with dry air, with relative humidity often less than $50 \%$ in late winter. The measurements of relative humidity were some of those that suffered from the changing agencies responsible for the towers. The near30 -year length of the record provides an excellent perspective on the cycles of rainfall in the central Canadian Prairies. The record drought from 1999 to 2002 (van der Kamp and Hayashi, 2009) during which annual rainfall averaged $20 \mathrm{~mm}$ is well documented and is in stark contrast to a recent wet period (Dumanski et al., 2015) when annual rainfall averaged $330 \mathrm{~mm}$ from 2005 to 2013 . A recent addition to the towers was a Geonor total precipitation gauge in 2014, but the 
record is too short to allow for a description of the entire precipitation regime at the site.

The mean maximum spring SWE as measured during the March snow surveys was $62 \mathrm{~mm}$ throughout the recorded period (1994-2017). There was a sustained period of lower than average SWE from 1998 to 2003, followed by an aboveaverage period from 2004 to 2009. The spring snowpack in 2013 was $120 \mathrm{~mm}$ and the largest in the 24-year period.

The water level variations in Wetland 1, 50, and 109 follow a distinct annual cycle that has a peak in pond level at the end of the snowmelt period, followed by a gradual decline during summer months. Wetland 109 contains a seasonal pond that dries out completely in some summers, may carry water over between years during wetter periods, and has reached spill elevation occasionally in recent wet years. The larger wetlands, Wetland 1 and 50, have permanent and semi-permanent ponds, respectively. Wetland 1 receives inflow in most years from a roughly 1000 ha watershed and spills to lower-lying ponds in most years, while Wetland 50 has never spilled during the period of record.

Wetland pond chemistry in the Prairies is controlled primarily by water balance components of evaporation, plant transpiration, and groundwater discharge. The long-term fluctuations in the chemistry of wetland ponds are caused by multiyear, wet-dry cycles associated with meteorological forcing and land use in the region (Cressey et al., 2016; Goldhaber et al., 2016, 2014; LaBaugh et al., 2016; Nachshon et al., 2014). During extreme wet conditions, groundwater discharge and surface runoff of salts from an upland area into freshwater ponds result in freshwater ponds becoming salinized (e.g., Wetland 109 and 120; Fig. 5). In addition to these water balance controls, geochemical and biochemical interactions within a wetland pond and underlying wetland soils also add or remove solutes from the wetland pond water (Heagle et al., 2007; LaBaugh et al., 2016; Pennock et al., 2014). Inadequate knowledge of the climate history and land use change around a particular pond could lead to a misinterpretation of the pond's hydrological function by shortterm observations of pond chemistry.

The maximum frost table depth is $\sim 1.2 \mathrm{~m}$ and corresponds with cold surface air temperature and low snowpack accumulation (Hayashi et al., 2003). The frost table depth is affected by antecedent soil water content during fall before the freeze (Pan et al., 2017). The saturated water content at freeze-up is usually 0.5 , with a high residual of liquid water content during frozen conditions. The variation in the water content values in different years might be attributed to heterogeneity and hydrological variation within the study area.

The stable water isotope compositions of precipitation, snowmelt, groundwater, and surface water (ponds) are similar to isotope values of water taken from surface ponds and glacial deposits throughout southern Saskatchewan and central Canada (Fortin et al., 1991; Fritz et al., 1987; Jasechko et al., 2014, 2017; Kelley and Holmden, 2001). The data show distinct differences between the different sources. The pre- cipitation data from SDNWA fall on the Saskatoon local meteoric water line (LMWL) but show distinct seasonal variability with winter measurements (snow) more depleted than summer rainfall. The pond water isotopes show evaporation like many surface waters. The shallow groundwater data are relatively similar to the pond data but subject to less evaporation. The intertill aquifer data are biased towards the snow end of the spectrum of precipitation.

\section{Data availability}

The SDNWA dataset is stored at the Federated Research Data Repository (FRDR) and can be accessed from the FRDR at https://doi.org/10.20383/101.0115 (Bam et al., 2018).

\section{Final remarks}

The data from the SDNWA have contributed significantly to our understanding of groundwater-surface water interactions in prairie environments. The long-term dataset can be used to examine the interannual variability of hydrological fluxes, climate change impact on wetlands, and groundwater resources. The unique dataset will be valuable to prairie hydrological research communities for various purposes such as inter-site comparison of hydrogeological processes or hydrological model testing.

Author contributions. EKPB provided the stable water isotopes and groundwater data, described sample collection and measurement, summarized the entirety of all the data, and put together the final drafts of the manuscript for comments. RB put together pond levels and snow surveys and meteorological data and plots, as well as the aerial map for SDNWA. SB compiled the soil moisture data, created plots, and wrote on instrumentation for the soil moisture data. AI discussed the relevant context of the hydrological data, wrote on the site description and hydrogeology, and provided edits and comments on the manuscript. CS wrote the Introduction, described the instrumentation for the meteorological data, and provided editorial comments on drafts. GV read through the final drafts of the manuscript and provided editorial help and reviews.

Competing interests. The authors declare that they have no conflict of interest.

Special issue statement. This article is part of the special issue "Water, ecosystem, cryosphere, and climate data from the interior of Western Canada and other cold regions". It is not associated with a conference.

Acknowledgements. The field program at SDNWA was assisted by field assistants, scientists, and institutions who are too many to name. We are especially grateful to the graduate students and 
post-doctoral fellows from the University of Saskatchewan who have conducted hydrological research projects at the SDNWA over the years. We also thank research and field technicians who took responsibility for data collection and quality control, especially Randy Schmidt, and Branko Zdravkovic and Amber Peterson, who assisted with data transfer and archiving. The efforts of the Canadian Consortium for Lidar Environmental Applications Research (C-CLEAR) team are also acknowledged for the lidar data acquisition. The program has been funded by the Natural Sciences and Engineering Research Council (Discovery Grant, CCRN), the National Hydrology Research Institute, Saskatoon, the Global Institute for Water Security, the University of Saskatchewan, and Environment and Climate Change Canada.

Review statement. This paper was edited by Chris DeBeer and reviewed by Willemijn Appels, Uri Nachshon, and one anonymous referee.

\section{References}

Bam, E., Brannen, R., Budhathoki, S., Ireson, A., Spence, C., and Van der Kamp, G.: Atmospheric, soil, surface and groundwater data from the St Denis National Wildlife Area, Saskatchewan, Canada, FRDR, https://doi.org/10.20383/101.0115, 2018.

Begley, I. S. and Scrimgeour, C. M.: High-precision $\delta^{2} \mathrm{H}$ and $\delta^{18} \mathrm{O}$ measurement for water and volatile organic compounds by continuous-flow pyrolysis isotope ratio mass spectrometry, Anal. Chem., 69, 1530-1535, https://doi.org/10.1021/ac960935r, 1997.

Berthold, S., Bentley, L. R., and Hayashi, M.: Integrated hydrogeological and geophysical study of depression-focused groundwater recharge in the Canadian prairies, Water Resour. Res., 40, W06505, https://doi.org/10.1029/2003WR002982, 2004.

Coleman, M. L., Shepherd, T. J., Durham, J. J., Rouse, J. E., and Moore, G. R.: Reduction of water with zinc for hydrogen isotope analysis, Anal. Chem., 54, 993-995, https://doi.org/10.1021/ac00243a035, 1982.

Campbell Scientific, Inc.: 229 Heat Dissipation Matric Water Potential Sensor Instruction Manual, Revision: 5/09, 2009.

Conly, F. M., Su, M., van der Kamp, G., and Millar, J. B.: A practical approach to monitoring water levels in prairie wetlands, Wetlands, 24, 219-226, 2004.

Coplen, T. B.: Normalization of oxygen and hydrogen isotope data, Chem. Geol., 72, 293-297, https://doi.org/10.1016/01689622(88)90042-5, 1988.

Cressey, R. L., Austin, J. E., and Stafford, J. D.: Three Responses of Wetland Conditions to Climatic Extremes in the Prairie Pothole Region, Wetlands, 36, 357-370, https://doi.org/10.1007/s13157016-0818-8, 2016.

Dumanski, S., Pomeroy, J. W., and Westbrook, C. J.: Hydrological regime changes in a Canadian Prairie basin, Hydrol. Process., 29, 3893-3904, 2015.

Eiler, J. M. and Kitchen, N.: Hydrogen-isotope analysis of nanomole (picoliter) quantities of $\mathrm{H}_{2} \mathrm{O}$, Geochim. Cosmochim. Ac., 65, 4467-4479, https://doi.org/10.1016/S00167037(01)00723-2, 2001.
Epstein, S. and Mayeda, T.: Variation of $\mathrm{O}^{18}$ content of waters from natural sources, Geochim. Cosmochim. Ac., 4, 213-224, https://doi.org/10.1016/0016-7037(53)90051-9, 1953.

Fortin, G., van der Kamp, G., and Cherry, J. A.: Hydrogeology and hydrochemistry of an aquifer-aquitard system within glacial deposits, Saskatchewan, Canada, J. Hydrol., 126, 262-292, 1991.

Fritz, P., Drimmie, R. J., Frape, S. K., and O'Shea, K.: The isotopic composition of precipitation and groundwater in Canada, in: Proceedings of an International Symposium on the use of Isotope Techniques In Water Resources Development Organized by the International Atomic Energy Agency in co-Operation with the United Nations Educational, Scientific And Cultural Organization and held in Vienna, 30 March-3 April 1987, IAEA (Ed), Austria, Vienna, 539-549, 1987.

Goldhaber, M. B., Mills, C. T., Morrison, J. M., Stricker, C. A., Mushet, D. M., and LaBaugh, J. W.: Hydrogeochemistry of prairie pothole region wetlands: Role of longterm critical zone processes, Chem. Geol. 387, 170-183, https://doi.org/10.1016/j.chemgeo.2014.08.023, 2014.

Goldhaber, M. B., Mills, C. T., Mushet, D. M., McCleskey, B. B., and Rover, J.: Controls on the Geochemical Evolution of Prairie Pothole Region Lakes and Wetlands over Decadal Time Scales, Wetlands, 36, 255-272, https://doi.org/10.1007/s13157016-0854-4, 2016.

Goodison, B. E., Glynn, J. E., Harvey, K. D., and Slater, J. E.: Snow surveying in Canada: A perspective, Can. Water Resour. J., 12, 27-42, 1987.

Hayashi, M. and van der Kamp, G.: Simple equations to represent the volume-area-depth relations of shallow wetlands in small topographic depressions, J. Hydrol., 237, 74-85, 2000.

Hayashi, M., van der Kamp, G., and Rudolph, D. L.: Water and solute transfer between a prairie wetland and adjacent uplands, 1. Water balance, J. Hydrol., 207, 42-55, 1998.

Hayashi, M., van der Kamp, G., and Schmidt, R.: Focused infiltration of snowmelt water in partially frozen soil under small depressions, J. Hydrol., 270, 214-229, 2003.

Hayashi, M., van der Kamp, G., and Rosenberry, D. O.: Hydrology of prairie wetlands: Understanding the integrated surfacewater and groundwater processes, Wetlands, 36, 237-254, https://doi.org/10.1007/s13157-016-0797-9, 2016.

Heagle, D., Hayashi, M., and van der Kamp, G.: Surfacesubsurface salinity distribution and exchange in a closed-basin prairie wetland, J. Hydrol., 478, 1-14, https://doi.org/10.1016/j.jhydrol.2012.05.054, 2013.

Heagle, D. J., Hayashi, M., and van der Kamp, G.: Use of solute mass balance to quantify geochemical processes in a prairie recharge wetland, Wetlands, 27, 806-818, 2007.

Hogan, J. M. and Conly, F. M.: St. Denis National Wildlife Area land cover classification: 1997, Canadian Wildlife Service, Prairie and Northern Region, Saskatoon, SK, Canada, Technical Report Series No. 384, 2002.

IAEA: Laser spectroscopic analysis of liquid water samples for stable hydrogen and oxygen isotopes, Isotope Hydrology Section, International Atomic Energy Agency (IAEA), Vienna, Austria, 49 pp., 2009.

Jasechko, S., Gibson, J. J., and Edwards, T. W. D.: Stable isotope mass balance of the Laurentian Great Lakes, J. Great Lakes Res., 40, 336-346, 2014. 
Jasechko, S., Wassenaar, L. I., and Mayer, B.: Isotopic evidence for widespread cold-season-biased groundwater recharge and young streamflow across central Canada, Hydrol. Process., 31, 21962209, 2017.

Karhu, J. A.: Catalytic reduction of water to hydrogen for isotopic analysis using zinc containing traces of sodium, Anal. Chem., 69, 4728-4730, https://doi.org/10.1021/ac9704467, 1997.

Kelley, L. I. and Holmden, C.: Reconnaissance hydrogeochemistry of economic deposits of sodium sulfate ( mirabilite ) in saline lakes , Saskatchewan, Canada, Hydrbiologia, 466, 279-289, https://doi.org/10.1023/A:1014565619506, 2001.

Kelly, S. D., Heaton, K. D., and Brereton, P.: Deuterium/hydrogen isotope ratio measurement of water and organic samples by continuous-flow isotope ratio mass spectrometry using chromium as the reducing agent in an elemental analyser, Rapid Commun. Mass Sp., 15, 1283-1286, https://doi.org/10.1002/rcm.303, 2001.

LaBaugh, J. W., Mushet, D. M., Rosenberry, D. O., Euliss, N. H., Goldhaber, M. B., Mills, C. T., and Nelson, R. D.: Changes in Pond Water Levels and Surface Extent Due to Climate Variability Alter Solute Sources to Closed-Basin PrairiePothole Wetland Ponds, 1979 to 2012, Wetlands, 36, 343-355, https://doi.org/10.1007/s13157-016-0808-x, 2016.

Lis, G., Wassenaar, L. I., and Hendry, M. J.: High-precision laser spectroscopy $\mathrm{D} / \mathrm{H}$ and $\delta^{18} \mathrm{O} / \delta^{16} \mathrm{O}$ measurements of microliter natural water samples, Anal. Chem., 80, 287-93, https://doi.org/10.1021/ac701716q, 2008.

Miller, J. J., Acton, D. F., and St. Arnaud, R. J.: The effect of groundwater on soil formation in a morainal landscape in Saskatchewan, Can. J. Soil Sci., 65, 293-307, 1985.

Minke, A. G., Westbrook, C. J., and van der Kamp, G.: Simplified volume-area-depth method for estimating water storage of prairie potholes, Wetlands, 30, 541-551, 2010.

Morgenstern, U. and Taylor, C. B.: Ultra low-level tritium measurement using electrolytic enrichment and LSC, Isot. Environ. Healt. S., 45, 96-117, https://doi.org/10.1080/10256010902931194, 2009.

Nachshon, U., Ireson, A., van der Kamp, G., Davies, S. R., and Wheater, H. S.: Impacts of climate variability on wetland salinization in the North American prairies, Hydrol. Earth Syst. Sci., 18, 1251-1263, https://doi.org/10.5194/hess-18-1251-2014, 2014.

Pan, X., Helgason, W., Ireson, A., and Wheater, H.: Field-scale water balance closure in seasonally frozen conditions, Hydrol. Earth Syst. Sci., 21, 5401-5413, https://doi.org/10.5194/hess-21-54012017, 2017.

Pennock, D., Yates, T., Bedard-Haughn, A., Phipps, K., Farrell, R., and McDougal, R.: Landscape controls on $\mathrm{N}_{2} \mathrm{O}$ and $\mathrm{CH}_{4}$ emissions from freshwater mineral soil wetlands of the Canadian Prairie Pothole region, Geoderma, 155, 308-319, 2010.

Pennock, D., Henderson, D., Naschon, U., Spence, C., van der Kamp, G., Waiser, M., Wilson, H., and Bedard-Haughn, A.: Where it all comes together - 45 years of research on the hydrology-ecosystem interactions at the St. Denis National Wildlife Area, Report completed for the Global Institute for Water Security, University of Saskatchewan, 84 pp., 2013.
Pennock, D., Bedard-Haughn, A., Kiss, J., and van der Kamp, G.: Application of hydropedology to predictive mapping of wetland soils in the Canadian Prairie Pothole Region, Geoderma, 235236, 199-211, https://doi.org/10.1016/j.geoderma.2014.07.008, 2014.

Rashford, B. S., Bastian, C. T., and Cole, J. G.: Agricultural landuse change in prairie Canada: implications for wetlands and waterfowl habitat conservation, Can. J. Agr. Econ., 59, 185-205, 2011.

Socki, R. A.: On-line technique for measuring stable oxygen and hydrogen isotopes from microliter quantities of water, Anal. Chem., 71, 2250-2253, https://doi.org/10.1021/ac981140i, 1999.

Spaans, E. J. A. and Baker, J. M.: Examining the use of time domain reflectometry for measuring liquid water content in frozen soil TDR Calibration, Water Resour. Res., 31, 2917-2925, 1995.

Statistics Canada: Table 002-0004 - Agriculture value added account, annual (dollars), CANSIM (database), Web service, 2017, available at: https://www150.statcan.gc.ca/t1/tbl1/en/tv.action? pid=3210004801 (4last access: 24 April 2018), 2017.

Stevens Water Monitoring Systems Inc.: The Hydra Probe ${ }^{\circledR}$ Soil Sensor, User's Manual, 1-63, July 2007.

Töyrä, J., Pietroniro, A., Craymer, M., and Véronneau, M: Evaluation of LiDAR-derived ground surface digital elevation model (DEM) in low-relief regions: Case study on the Canadian Prairies, in: Hydroscan: Airborne laser mapping of hydrologic features and resources, edited by: Hopkinson, C., Pietroniro, A., and Pomeroy, J. W., Canadian Water Resources Association, 301-326, 2008.

van der Kamp, G. and Hayashi, M.: Groundwater-wetland ecosystem interaction in the semiarid glaciated plains of North America, Hydrogeol. J., 17, 203-214, 2009.

van der Kamp, G., Keir, D., and Evans, M. S.: Long-term water level changes in closed-basin lakes of the Canadian prairies, Can. Water Resour. J., 33, 23-38, 2008.

van der Kamp, G., Stolte, W. J., and Clark, R. G.: Drying out of small prairie wetlands after conversion of their catchments from cultivation to permanent brome grass, Hydrolog. Sci. J., 44, 387 397, 1999.

Waiser, M. J.: Relationship between hydrological characteristics and dissolved organic carbon concentration and mass in northern prairie wetlands using a conservative tracer approach, J. Geophys. Res., 111, G02024, https://doi.org/10.1029/2005JG000088, 2006.

Woo, M. K. and Rowsell, R. D.: Hydrology of a prairie slough, J. Hydrol., 146, 175-207, 1993. 